\title{
Trisomy 8: a common finding in mouse embryonic stem (ES) cell lines
}

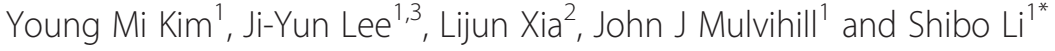

\begin{abstract}
Background: Obtaining a germ cell line is one of the most important steps in developing a transgenic or knockout mouse with a targeted mutated gene of interest. A common problem with this technology is that embryonic stem (ES) cells often lack, or are extremely inefficient at, germ line transmission.

Results: To determine whether chromosomal anomalies are correlated with inefficient ES cell germ line transmission, we examined 97 constructed ES cell lines using conventional cytogenetic analysis, and fluorescence in situ hybridization (FISH). Chromosomal abnormalities occurred in 44 (45\%) out of the 97 specimens analyzed: 31 specimens had trisomy 8 or mosaic trisomy 8 , eight specimens had partial trisomy 8 resulting from unbalanced translocations, and five specimens had other chromosomal anomalies.
\end{abstract}

Conclusions: Our data suggest that chromosomal analysis is an important tool for improving the yield and quality of gene targeting experiments.

Keywords: Mouse ES cells, Chromosomal aberrations, FISH, Mosaicism

\section{Background}

Although the whole human genome has now been sequenced, determining the function of each gene in the human body remains a challenge. A practical and frequent approach to studying human gene function is to use mouse models, accomplished by direct mutagenesis through targeting mouse embryonic stem (ES) cells. Established mouse ES cell lines have the ability to maintain unlimited proliferation in vitro and differentiate into a variety of cell lineages including germ cells [1]. The ability to obtain a germ line is one of the most important steps in developing a transgenic or knockout mouse with a specific mutated gene. However, a common problem with this valuable technique is that the ES cells often lack or have a low efficiency of germ line transmission. Thus, understanding what affects the efficiency of germ line transmission is crucial to developing transgenic and knockout mice.

Many factors determine the efficiency of germ line transmission [2]. Chromosome make-up clearly affects both somatic cell chimerism and germ line transmission.

\footnotetext{
* Correspondence: shibo-li@ouhsc.edu

1 Department of Pediatrics, The University of Oklahoma Health Sciences

Center, Oklahoma City, OK 73104, USA

Full list of author information is available at the end of the article
}

For example, ES cells with trisomy 8 are significantly less efficient at achieving other germ line transmission than cells with normal karyotypes [3]. Aneuploid ES cells have very low germ line transmission [4]. Chimeric mice obtained from chromosomally abnormal ES cells often have phenotypic abnormalities beyond those of pretargeted gene [5]. This abnormal genotype makes correlating the genotype and phenotype in chimeric mice extremely difficult, if not impossible.

It is not clear why structural and numerical chromosome abnormalities are found in ES cell lines subjected to extended culture in vitro. One hypothesis is that the changes confer a proliferative benefit to those cells (favorable selection). Cell aging is another possible explanation. The frequency of chromosomal anomalies increases with passage of cells in culture $[4,6]$; for example, a de novo Robertsonian translocation between homologous chromosomes 11 was spontaneously induced [7].

To qualify this troublesome phenomenon, we analyzed the chromosome of 97 mouse ES cell lines using conventional cytogenetic technique and fluorescence in situ hybridization (FISH). 


\section{Results}

Of the 97 ES cell lines examined, 44 (45\%) had either numerical or structural changes or a combination of both (Table 1). Among these abnormal ES cell lines, 31 had numerical changes, seven cell lines had structural changes and six cell lines had both numerical and structural changes.

In 31 cell lines with numerical changes, 16 (52\%) were pure trisomy $8(41, \mathrm{XY},+8)$ (Table 2 , Figure $1 \mathrm{~A})$, six had mosaic trisomy $8(41, \mathrm{XY},+8 / 40, \mathrm{XY})$ and two had double trisomies of chromosomes 8 and $11(42, \mathrm{XY},+8,+11)$. The remaining seven cell lines had either mosaic or pure trisomies of chromosome $8(6 / 7)$, chromosome $11(4 / 7)$ or chromosome Y (3/7). One cell line had a loss of the $Y$ chromosome.

Seven of the 97 cell lines (7\%) had structural abnormalities (Table 3). Two of these seven cell lines had Robertsonian translocations between chromosomes 2 and 8 [40,XY,der(2)t(2;8)(A1;A1)] (Figure 1B) and chromosomes 8 and 13 [40,XY,der(13)t(8;13)(A1;A1)] (Figure 1C). One cell line had an apparently balanced translocation between chromosomes 6 and 12 [40,XY,t $(6 ; 12)(F 3 ; D 3)]$ (Figure 1D). Two cell lines had a derivative chromosome 17 due to an unbalanced translocation between chromosomes 8 and 17 [40,XY,der(17)t $(8 ; 17)$ (B2;E2)] (Figure 2A), which was also confirmed by FISH (Figure 2B). One cell line had a mosaic interstitial deletion of the long arm of chromosome 6 at the breakpoints of B1 and C3 [40,XY, del(6)(B1C3)/40,XY]. One cell line had two clones with chromosomal changes, each including an unbalanced translocation between chromosomes 8 and 14, plus one clone has a deletion of chromosome 7 at band F2 [40,XY,der(14)t $(8 ; 14)(\mathrm{C} 3 ; \mathrm{E} 5) / 40, \mathrm{XY}, \operatorname{del}(7)(\mathrm{F} 2), \operatorname{der}(14) \mathrm{t}(8 ; 14)(\mathrm{C} 3 ; \mathrm{E} 5)]$. In the cell lines with structural abnormalities, five out of seven had extra chromosome 8 materials of various sizes ranging from the whole arm to a partial duplication of chromosome 8 .

Six cell lines also had mixtures of both numerical and structural changes (Table 4). Among six cell lines, two cell lines had an extra $\mathrm{Y}$ chromosome, plus a derivative chromosome 1 due to an unbalanced translocation between chromosomes 1 and $8[41, \mathrm{XY},+\mathrm{Y}, \operatorname{der}(1) \mathrm{t}(1 ; 8)$

Table 1 Summary of cytogenetic findings in all 97 mouse ES cell lines

\begin{tabular}{lcc}
\hline Cytogenetic findings & Number of cell lines & \% \\
\hline Normal karyotype & 53 & 55 \\
Numerical changes (Table 2) & 31 & 32 \\
Structural changes (Table 3) & 7 & 7 \\
$\begin{array}{l}\text { Both numerical and structural } \\
\text { changes (Table 4) }\end{array}$ & 6 & 6 \\
\hline Total & $\mathbf{9 7}$ & $\mathbf{1 0 0}$ \\
\hline
\end{tabular}

Table 2 Summary of numerical anomalies in mouse ES cell lines

\begin{tabular}{lc}
\hline Numerical anomalies & Number of cell lines \\
\hline $43, X Y,+Y,+8,+11$ & 1 \\
$41, X Y,+Y / 42, X Y,+Y,+8 / 40, X Y$ & 1 \\
$41, X Y,+Y / 41, X Y,+8 / 42, X Y,+3,+7$ & 1 \\
$40, X,-Y,+8 / 40, X,-Y,+11 / 41, X,-Y,+6,+8 / 41, X,-Y$, & 1 \\
$+6,+11 / 42, X Y,+6,+8 / 42, X Y,+6,+11 / 40, X Y$ & \\
$41, X Y,+8$ & 16 \\
$41, X Y,+8 / 40, X Y$ & 6 \\
$42, X Y,+8,+11$ & 2 \\
$42, X Y,+8,+15$ & 1 \\
$41, X Y,+11$ & 1 \\
$44, X Y,+1,+6,+8,+11$ & 1 \\
\hline Total & $\mathbf{3 1}$ \\
\hline
\end{tabular}

(A1;D1)] (Figure 2C,D). One cell line had a translocation between chromosomes 4 and 14, plus an extra chromosome $6[41, \mathrm{XY}, \mathrm{t}(4 ; 14)(\mathrm{C} 6 ; \mathrm{E} 5),+6]$. One cell line had three different clones, [41,XY,+3/40,XY,der(17)t(8;17)(B2;E2)/40, $\mathrm{XY}$ ]. Another cell line also had three independent clones [40,XY,del(6)(B1C3)/41,XY,+4/40,XY]. The last cell line had two clones with a deletion of chromosome 10 and trisomy 8 [40,XY,del(10)(A4C1)/41,XY,+8,del(10)(A4C1)]. Four out of six cell lines had an extra chromosome 8 or a partially duplicated chromosome 8 . The smallest partial duplications of chromosome 8 were from the band D1 to the terminus of chromosome 8 , which found in the two cell lines with 41,XY,+Y,der(1)t(1;8)(A1;D1).

\section{Discussion}

Analyses of mouse ES cell lines performed in our laboratory revealed a high rate of chromosomal abnormalities. Forty-four out of 97 ES cell lines (45\%) showed abnormal karyotypes. Chromosomal abnormalities associated with chromosome 8 , i.e., trisomy 8 or mosaic trisomy 8 or partial trisomy 8 due to an unbalanced translocation, accounted for $89 \%$ of all abnormalities (39 out of 44). Similar findings have been reported by other investigators $[3,9,10]$. ES cell clones with trisomy 8 have shown to have a selective growth advantage, and while they readily produce chimeras, they do not transmit the mutation to the germ line [3]. After trisomy 8, trisomy of chromosome 11 (6 out of 44) is the second most frequent abnormality in the karyotype analysis of ES cells, as also noted before $[7,10]$.

The mechanism for these chromosomal abnormalities is not known, despite those frequencies. Generally, cells in vitro for numerous passages acquire chromosomal changes. The proportion of euploid cells starts to decrease abruptly after passage 15 , and only 20 to $30 \%$ of cells remain euploid by passage 25 [5,11]. The efficiency of germ line transmission declines as the ES cell passage 


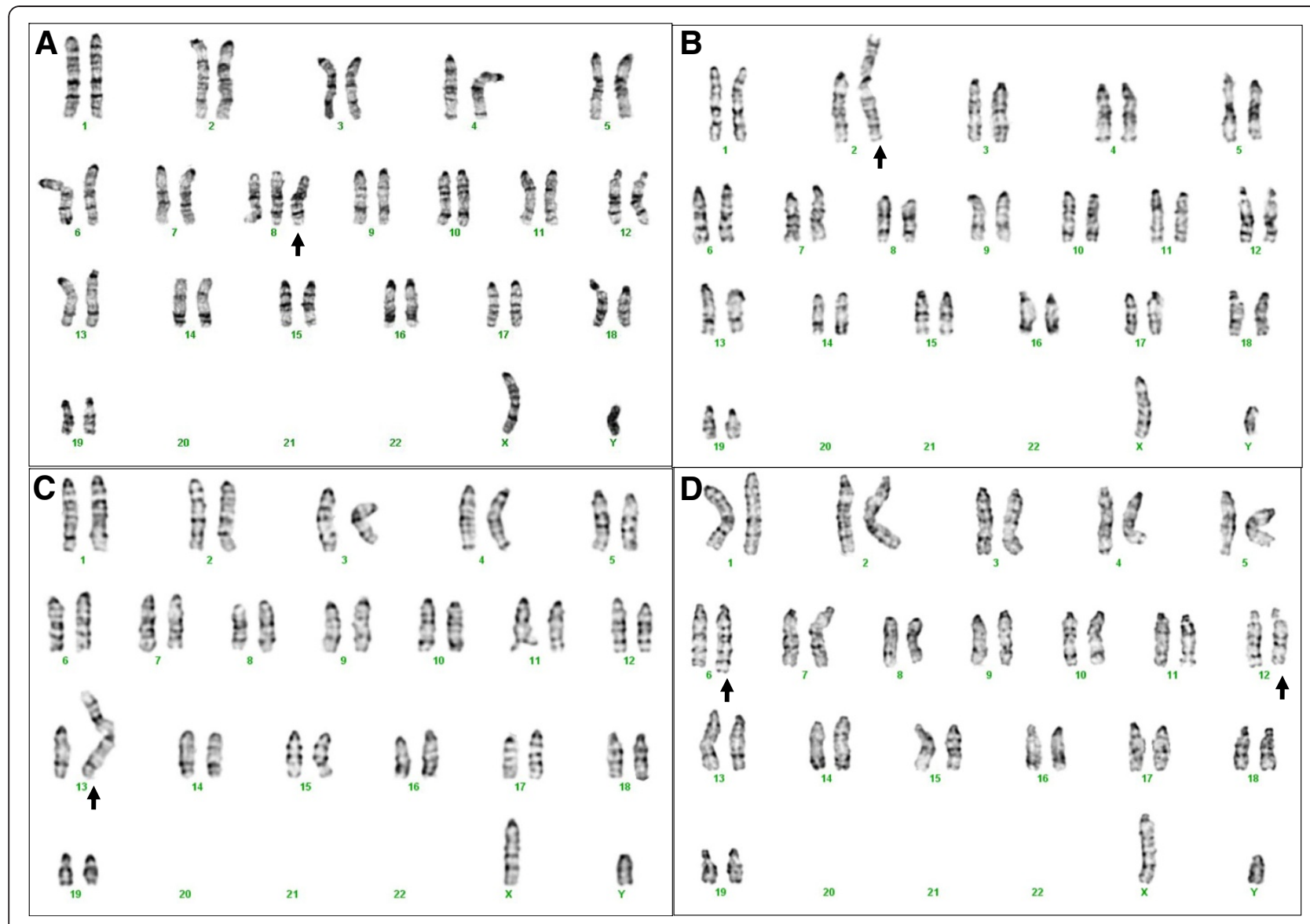

Figure 1 Conventional G-banded karyotypes with numerical and structural anomalies. $(A): 41, X Y,+8$. (B): 40,XY, der(2)t(2;8)(A1;A1). (C): 40,XY, $\operatorname{der}(13) t(8 ; 13)(A 1 ; A 1)$. (D) 40,XY,t(6;12)(F3;D3). Arrows show the abnormal chromosomes.

number increases in number, at least partially due to the presence of aneuploidy in the cell population [5,12].

On average, the ES cells used for this study had undergone at least fifteen to twenty passages. For this reason, we conclude that extended culture in vitro is at least one causative factor for the high frequency of chromosomal abnormalities. Although we were unable to identify all the mouse strains in our collection, we were able to positively identify 46 ES cell lines from four major

Table 3 Summary of structural anomalies in mouse ES cell lines

\begin{tabular}{lc}
\hline Structural anomalies & Number of cell lines \\
\hline $40, X Y, \operatorname{der}(2) t(2 ; 8)(\mathrm{A} 1 ; \mathrm{A} 1)$ & 1 \\
$40, \mathrm{XY}, \operatorname{del}(6)(\mathrm{B} 1 \mathrm{C} 3) / 40, \mathrm{XY}$ & 1 \\
$40, \mathrm{XY}, \mathrm{t}(6 ; 12)(\mathrm{F} 3 ; \mathrm{D} 3)$ & 1 \\
$40, \mathrm{XY}, \operatorname{der}(13) \mathrm{t}(8 ; 13)(\mathrm{A} 1 ; \mathrm{A} 1)$ & 1 \\
$40, \mathrm{XY}, \operatorname{der}(14) \mathrm{t}(8 ; 14)(\mathrm{C} 3 ; \mathrm{E} 5) / 40, \mathrm{XY}, \operatorname{del}(7)(\mathrm{F} 2)$, & 1 \\
$\operatorname{der}(14) \mathrm{t}(8 ; 14)(\mathrm{C} 3 ; \mathrm{E} 5)$ & \\
$40, \mathrm{XY}, \operatorname{der}(17) \mathrm{t}(8 ; 17)(\mathrm{B} 2 ; \mathrm{E} 2)$ & 2 \\
\hline Total & $\mathbf{7}$ \\
\hline
\end{tabular}

mouse strains, AB2.2, CJ7, GSI-1, and J1. Among them, 15 cell lines were derived from the AB2.2 mouse strain, 24 from CJ7, 3 from GSI-1 and 4 from J1. Interestingly, we found that the cell line AB2.2 had chromosomal abnormalities with mosaic trisomy $8,[42, X Y,+Y,+8 / 41$, $\mathrm{XY},+\mathrm{Y} / 40, \mathrm{XY}]$. Also, its sub-ES cell lines showed various karyotypic abnormalities.

Of the 11 sub-ES cell lines, two were normal, four were trisomy 8 , one was mosaic trisomy 8 , two were double trisomy with chromosomes 8 and 11 and one was derivative chromosome 14 resulting from an unbalanced translocation between chromosomes 8 and 14. The most interesting finding is that one of the sub-ES cell lines showed very complex numerical chromosome abnormalities, including the most common numerical abnormalities found in our study: 40, $\mathrm{X},-\mathrm{Y},+8 / 40, \mathrm{X},-\mathrm{Y},+11 / 41, \mathrm{X},-\mathrm{Y},+6,+8 / 41, \mathrm{X},-\mathrm{Y},+6,+11 / 42, \mathrm{XY},+6$, $+8 / 42, \mathrm{XY},+6,+11 / 40$, $\mathrm{XY}$. We were not able to follow up on whether or not this cell line affected other ES cell lines.

\section{Conclusions}

We have performed chromosomal analysis of 97 constructed ES cell lines. Chromosomal anomalies were seen 


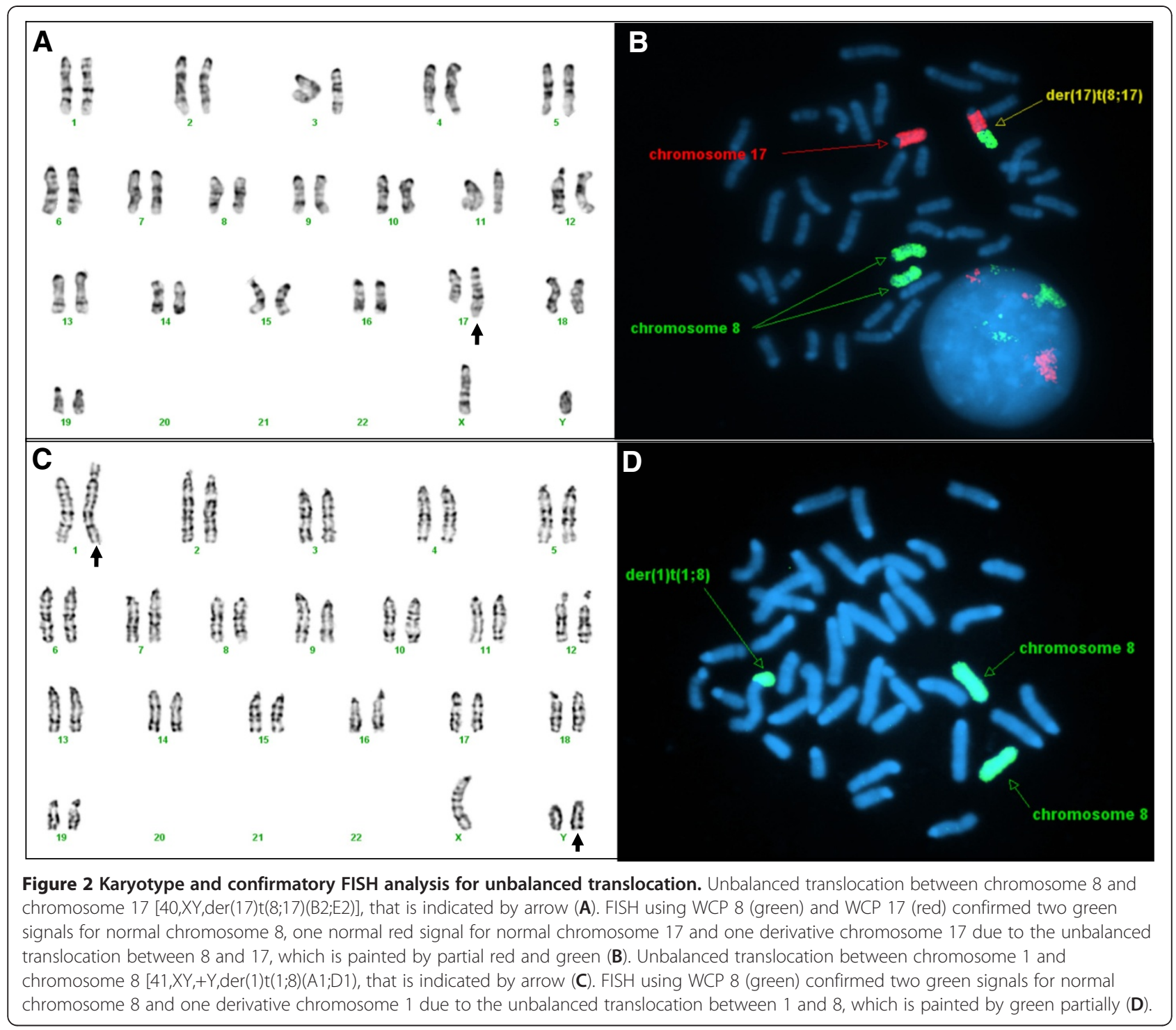

in 44(45\%) out of the specimens analyzed. We found trisomy 8 to be a common anomaly in the sub-ES cell lines identified from the original mouse strains. It is not uncommon that ES cells with trisomy 8 over-proliferate. This should serve as a warning for collaborative researchers attempting to maximize their limited resources by growing

\section{Table 4 Summary of both numerical and structural} anomalies in mouse ES cell lines

\begin{tabular}{lc}
\hline Structural and numerical anomalies & Number of cell lines \\
\hline $41, X Y,+Y, \operatorname{der}(1) t(1 ; 8)(A 1 ; D 1)$ & 2 \\
$41, X Y, t(4 ; 14)(C 6 ; E 5),+6$ & 1 \\
$41, X Y,+3 / 40, X Y, \operatorname{der}(17) t(8 ; 17)(B 2 ; E 2) / 40, X Y$ & 1 \\
$40, X Y, \operatorname{del}(6)(B 1 C 3) / 41, X Y,+4 / 40, X Y$ & 1 \\
$40, X Y, \operatorname{del}(10)(A 4 C 1) / 41, X Y,+8, \operatorname{del}(10)(A 4 C 1)$ & 1 \\
\hline Total & $\mathbf{6}$ \\
\hline
\end{tabular}

more and more ES cells before sharing their clones. Our findings indicate that before the injection of ES cells into blastocysts, karyotype analysis by conventional methods including FISH analysis is needed in order to ensure genome stability.

\section{Methods}

All the experiments were performed on the established cell lines obtained from mice. No ethical issues is applied to this study.

ES cell lines

Ninety-seven ES cell lines obtained from various research teams at the University of Oklahoma Health Sciences Center and the Oklahoma Medical Research Foundation between 2000 and 2006. The ES cell lines were of multiple origins, obtained either from commercial or academic 
sources, with different gene constructs. We were able to examine the AB2.2, CJ7, GSI-1 and J1 ES cell lines. Some cell lines originated from one single source and were expanded in different laboratories for at least another five to ten passages (1:3 or 1:4 splits) in culture under varying conditions. Thus, the cells used for this study had all undergone at least fifteen to twenty passages.

\section{Chromosome preparation and karyotype analysis}

The standard procedures for harvesting, making slides and staining the cells were followed [8]. ES cells were arrested in metaphase by adding colcemid (final concentration of $0.02 \mu \mathrm{g} / \mathrm{ml}$ ) to the culture medium for one hour. The cells were then washed in phosphate buffered saline (PBS). After trypsin treatment, detached cells were spun down. A hypotonic solution $[0.075 \mathrm{M}$ potassium chloride $(\mathrm{KCl})]$ was added, and cells were incubated for $30 \mathrm{~min}$ at $37^{\circ} \mathrm{C}$ prior to fixation. Fixation with 3:1 methanol:glacial acetic acid was performed three times prior to spreading the cells on glass slides. Twenty cells were analyzed for each line and at least five cells were karyotyped with standard nomenclature [13].

\section{Fluorescent in situ hybridization (FISH)}

The whole chromosome painting probes (WCP) for chromosomes 8, 10,14 and 17 were purchased from a commercial source (Cambio, UK) for the ES cell lines with complex chromosomal abnormalities. FISH analysis was performed according to the manufacturer's instructions.

\section{Abbreviations}

ES: Embryonic stem; FISH: Fluorescence in situ hybridization; PBS: Phosphate buffered saline; KCl: Potassium chloride; WCP: Whole chromosome painting probes.

\section{Competing interests}

The authors declare that they have no competing interests.

\section{Authors' contributions}

YK collected and/or assembly of data analysis and interpretation. $J$ carried data analysis and interpretation. LX provided of study material. JM participated in final approval of manuscript. SL conceived of the study concept and design, and participated in data analysis and interpretation, and final approval of manuscript. All authors read and approved the final manuscript.

\section{Acknowledgements}

The authors would like to express their thanks to the laboratory technicians, especially Fransesca Bates, who initiated the testing assay in our laboratory.

\section{Author details}

${ }^{1}$ Department of Pediatrics, The University of Oklahoma Health Sciences Center, Oklahoma City, OK 73104, USA. ${ }^{2}$ Cardiovascular Biology Research Program, Oklahoma Medical Research Foundation, Oklahoma City, OK 73104, USA. ${ }^{3}$ Department of Pathology, Korea University, Seoul 136-705, South Korea.

Received: 28 August 2012 Accepted: 6 December 2012

Published: 16 January 2013

\section{References}

1. Smith AG: Embryo-derived stem cells: of mice and men. Annu Rev Cell Dev Biol 2001, 17:435-462.
2. Carstea AC, Pirity MK, Dinnyes A: Germline competence of mouse ES and iPS cell lines: chimera technologies and genetic background. World J Stem Cells 2009, 31:22-29.

3. Liu X, Wu H, Loring J, Hormuzdi S, Disteche CM, Bornstein P, Jaenisch R: Trisomy eight in ES cells is a common potential problem in gene targeting and interferes with germ line transmission. Dev Dyn 1997, 209:85-91.

4. Nagy A, Rossant J, Nagy R, Abramow-Newerly W, Roder JC: Derivation of completely cell culture-derived mice from early-passage embryonic stem cells. Proc Natl Acad Sci 1993, 90:8424-8428.

5. Longo L, Bygrave A, Grosveld FG, Pandolfi PP: The chromosome make-up of mouse embryonic stem cells is predictive of somatic and germ cell chimaerism. Transgenic Res 1997, 6:321-328.

6. Brown DG, Willington MA, Findlay I, Muggleton-Harris L: Criteria that optimize the potential of murine embryonic stem cells for in vitro and in vivo developmental studies. In Vitro Cell Dev Viol 1992, 28A:773-778.

7. Crolla JA, Brown D, Whittingham DG: Spontaneous induction of an homologous Robertsonian translocation, $\mathrm{Rb}(11.11)$ in a murine embryonic stem cell line. Genet Res Camb 1990, 55:107-110.

8. Evans M: Tissue culture of embryonic stem cells. In Cell biology: A laboratory handbook. Volume 1. 2nd edition. Edited by Celis JE. San Diego: Academic Press; 1998:86-97.

9. Guo J, Jauch A, Holtgreve-Grez H, Schoell B, Erz D, Schrank M, Janssen JWG: Multicolor karyotype analyses of mouse embryonic stem cells. In Vitro Cell Dev Biol Anim 2005, 41A:278-283.

10. Sugawara A, Goto K, Sotomaru $Y$, Sofuni T, Ito T: Current status of chromosomal abnormalities in mouse embryonic stem cell lines used in Japan. Comp Med 2006, 56:31-34.

11. Rebuzzini P, Neri T, Mazzini G, Zuccotti M, Redi CA, Garagna S: Karyotype analysis of the euploid cell population of a mouse embryonic stem cell line revealed a high incidence of chromosome abnormalities that varied during culture. Cytogenet Genome Res 2008, 121:18-24.

12. Saksela E, Moorhead PS: Aneuploidy in the degenerative phase of serial cultivation of human cell strains. Proc Natl Scad Sci 1963, 50:390-395.

13. Nesbitt MN, Frankcke U: A system of nomenclature for band patterns of mouse chromosomes. Chromosoma 1973, 41:145-158.

doi:10.1186/1755-8166-6-3

Cite this article as: Kim et al:: Trisomy 8: a common finding in mouse embryonic stem (ES) cell lines. Molecular Cytogenetics 2013 6:3.

\section{Submit your next manuscript to BioMed Central and take full advantage of:}

- Convenient online submission

- Thorough peer review

- No space constraints or color figure charges

- Immediate publication on acceptance

- Inclusion in PubMed, CAS, Scopus and Google Scholar

- Research which is freely available for redistribution 